\title{
Properties of cement mortars in fresh and hardened condition influenced by combined application of SCMs
}

LILLA MLINÁRIK - BME , Dept. of Engineering Geology and Geotechnics - lilla.mlinarik@gmail.com KatALIN KOPECSKÓ PHD - BME, Dept. of Engineering Geology and Geotechnics - katalin@eik.bme.hu AdoRJÁn BOROSNYÓI PHD - BME, Dept. of Construction Materials and Technologies

- borosnyoi.adorjan@epito.bme.hu

Érkezett: 2016. 01. 18. " Received: 18. 01. 2016. " http://dx.doi.org/10.14382/epitoanyag-jsbcm.2016.11

\begin{abstract}
In the hardened cement paste - through pozzolanic reactions - additional hydration products can be formed by the use of supplementary cementing materials (SCMs). The expected results of these processes are: increase in strength, decrease in permeability and the improvement of other important durability properties.

In the present research, properties of mortar mixtures were investigated with different cement substitution rates of SCMs both in fresh and hardened conditions. The consistence of mixtures was determined by flow table test, and the change in workability was repeatedly measured until 120 minutes. The specimens were stored in water up to the age of 7 days then under laboratory conditions (in climate chamber of $20 \pm 3^{\circ} \mathrm{C}$ temperature and $\mathrm{RH}=65 \%$ relative humidity) up to the age of 28 days. Afterwards half of the specimens were immersed into and stored under water and the other half was kept continuously under laboratory conditions. The properties of the hardened specimens (flexural tensile strength, compressive strength, water absorption, apparent density and apparent porosity) were investigated at the age of 28, 56, 90 days. Seven mortar mixtures were made of CEM I $42.5 \mathrm{~N}$ Portland cement with different cement substitution ratios of metakaolin (MK) and/or silica fume (SF). Quartz sand was used as aggregate with the range of $0 / 2 \mathrm{~mm}$ particle size. The results of consistence measurements showed that the flow values of the fresh mortar mixtures which contain SCMs are smaller comparing with the reference mixtures (without SCMs), since the physical properties of these materials (particle size, specific surface area, particle shape, etc.) influence the consistence. The specimens with smaller substitution ratio showed more effective utilization of SCMs in the view of strength. The water absorption and apparent porosity were higher, and at the same time the apparent density was smaller than those of the mixtures with higher substitution ratios.

Keywords: supplementary cementing materials, fresh mortar, hardened mortar, consistence, strength
\end{abstract}

Lilla MLINÁRIK Chemical Engineer (MSc, 2012). Graduated at the Department of Physical Chemistry and Materials Science, Budapest University of Technology and Economics. Started her research work in 2009 in the field of concrete admixtures (superplasticizers). Since 2015, she has been PhD candidate at the Budapest University of Technology and Economics, Department of Engineering Geology and Geotechnics. Her field of research is the influence of supplementary cementing materials on the chemical resistance of cements.

Katalin KOPECSKó, PhD

MSc in Chemical Engineering, postgraduate engineering degree in Concrete Technology, PhD, associate professor at BME, Dept. of Engineering

Geology and Geotechnics. Main research fields: cement hydration, supplementary cementing materials, durability of concrete and construction materials, X-ray diffraction (XRD) and thermoanalytics (TG/DTG/DTA). Member of the Technical Committee MSZT/MT 102 "Cement and Lime" for Hungarian, European and international standardization and standardization programmes

Adorján BOROSNYól, PhD Civil engineer (MSc), PhD, associate professor at the Department of Construction Materials and Technologies, Budapest University of Technology and Economics. Main fields of interest: durability of concrete structures, supplementary cementing materials, application of non-metallic (FRP) reinforcements for concrete structures, bond in concrete, non-destructive testing of concrete. Member of fib T2.1 „Serviceability Models (COM1 Concrete Structures), fib T5.1 „FRP Reinforcement for concrete structures" (COM5 Reinforcements), RILEM Technical Committee ISC "Non destructive in situ strength assessment of concrete".

\section{Introduction}

The environmental impact of the cement industry is significant [1]. Nowadays, the development of eco- and environmentally friendly construction materials are among the main objectives of concrete research [2]. New supplementary cementing materials (SCMs) are able to reduce the rate of environmental pollution from production processes and able to decrease ecological footprint $[3,4]$.

The reduction of $\mathrm{CO}_{2}$ emission could be reached by the application of SCMs. These materials are usually industrial byproducts and, therefore, the production of these materials does not increase the $\mathrm{CO}_{2}$ emission of the cement industry. The amount of the used cement can be also reduced by the use of SCMs [5].

In the present research metakaolin (MK) and silica fume (SF) were studied. The metakaolin was made from kaolin by thermal activation, and the silica fume was a by-product of silicon and ferrosilicon alloy production $[6,7,8]$. The concrete structures, which contain these types of SCMs, could be applied in corrosive environment, like water treatment plants, sewage plants and systems, agricultural silos or slurry storage tanks [9]. These fields develop rapidly and it is very important to get more knowledge of the applied materials [10-14].

\section{Materials and methods}

In the present study, the effects of metakaolin (MK) and silica fume (SF) SCMs were investigated on the properties cement mortars in both fresh and hardened condition. Determined amounts of cement were substituted by the SCMs. The applied cement was CEM I $42.5 \mathrm{~N}$ Portland cement, the MK was in powder from, and the SF was in slurry form. The applied cement content was $520 \mathrm{~kg} / \mathrm{m}^{3}$. Seven mixtures of mortar were prepared with the same water to binder ratio $(\mathrm{w} / \mathrm{b}$ $=0.4$ ), and the reference samples were made without SCMs. The water content of the slurry was $50 \mathrm{~m} \%$ and it has been considered in the calculation of $\mathrm{w} / \mathrm{b}$ ratio. Two mixtures were prepared with different amounts of MK, another two with different amounts of SF, while two mixtures contained MK and SF combined (Table 1). In the specimens, quartz sand was used as aggregate with the particle size of $0 / 2 \mathrm{~mm}$. The ratios of the sand fractions were the following: $1 / 2 \mathrm{~mm} 40 \mathrm{~m} \%, 0.2 / 1 \mathrm{~mm}$ $42 \mathrm{~m} \%$, F $36(0.08-0.25 \mathrm{~mm}) 18 \mathrm{~m} \%$. The dimension of the prismatic specimens was $40 \times 40 \times 160 \mathrm{~mm}$.

The specimens were stored under water up to 7 days then in climatic chamber up to 28 days $\left(20 \pm 3^{\circ} \mathrm{C}\right.$ temperature and $\mathrm{RH}=65 \%$ relative humidity). Half of the specimens were kept in 
the climatic chamber until the age of testing, and the other half was immersed into and stored under water until the age of testing. The consistence was measured by flow table test and the workability was repeatedly determined on the fresh mortar up to 120 minutes after mixing. Flexural tensile strength and compressive strength were determined on the hardened mortar specimens. Water absorption, apparent porosity, and apparent density were measured as well. The measurements on the hardened samples were carried out at the age of 28,56 and 90 days.

\begin{tabular}{lccccc} 
& $\begin{array}{c}\text { Mixture } \\
\text { designation }\end{array}$ & $\begin{array}{c}\text { Cement } \\
{[\mathbf{m} \%]}\end{array}$ & MK [m\%] & SF [m\%] & $\begin{array}{c}\text { MK+SF } \\
{[\mathbf{m} \%]}\end{array}$ \\
\hline $\mathbf{1}$ & CEM I & 100 & - & - & - \\
\hline $\mathbf{2}$ & MK 10 & 90 & 10 & - & - \\
\hline $\mathbf{3}$ & MK 17 & 83 & 17 & - & - \\
\hline $\mathbf{4}$ & SF 5 & 95 & - & 5 & - \\
\hline $\mathbf{5}$ & SF 10 & 90 & - & 10 & - \\
\hline $\mathbf{6}$ & MK/SF 7/3 & 90 & 7 & 3 & $7+3=10$ \\
\hline $\mathbf{7}$ & MK/SF 12/5 & 83 & 12 & 5 & $12+5=17$
\end{tabular}

Table 1. Composition of mortar mixtures

1.táblázat Habarcs keverékek összetétele

\section{Results and discussion}

\subsection{Properties in fresh condition}

Consistence of the fresh mortars was tested by flow table test, according to the EN 1015-3:1999/A2:2006 European Standard [15]. The flow value was determined by measuring the mean diameter of the test samples. The water to binder ratio and the amount of the superplasticizer was the same for each mixture. According to the results, it can be found that the flow values of the fresh mortars with the use of SCMs are smaller than those of the reference mixture (Fig.1).

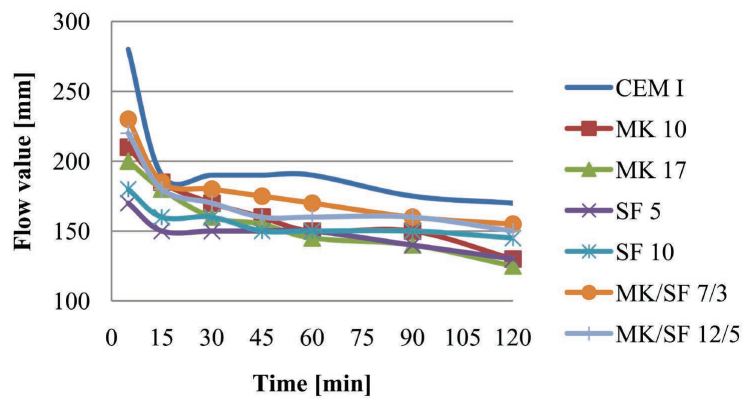

Fig. 1. Change of flow values in time

1. ábra Terülés mértékének időbeli változása

Differences were observed between the properties of the mixtures in the fresh condition. With the addition of SCMs, the total surface area of the particles in the mixtures was increased, since the average particle size of the SCMs is smaller than that of the cement. The median particle size for cement is $10 \mu \mathrm{m}$, for silica fume is $0.1 \mu \mathrm{m}$, and for metakaolin is $1.3 \mu \mathrm{m}$ [16]. There is also some difference in the shape of the particles (see Figs. 2 and 3). Particles of MK have lamellar shape, while particles of SF are more spherical. The observed differences in the consistence are attributed to these reasons. Fig. 4 indicates the differences of the initial and final flow values of the mixtures.

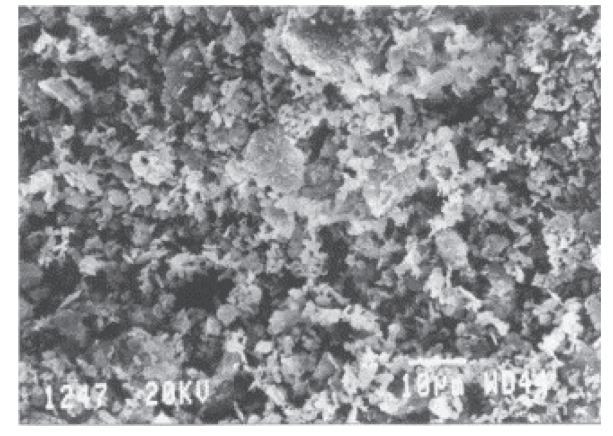

Fig. 2. Scanning electron microscopic observation of metakaolin [17] 2. ábra Metakaolin pásztázó elektronmikroszkópos felvétele [17]

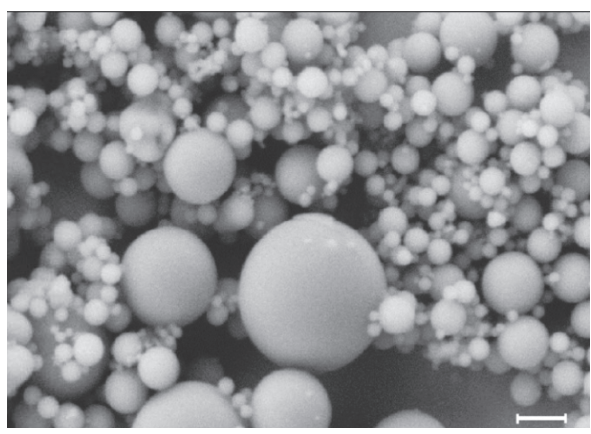

Fig. 3. Scanning electron microscopic observation of silica fume [18]

3. ábra Szilikapor pásztázó elektronmikroszkópos felvétele [18]

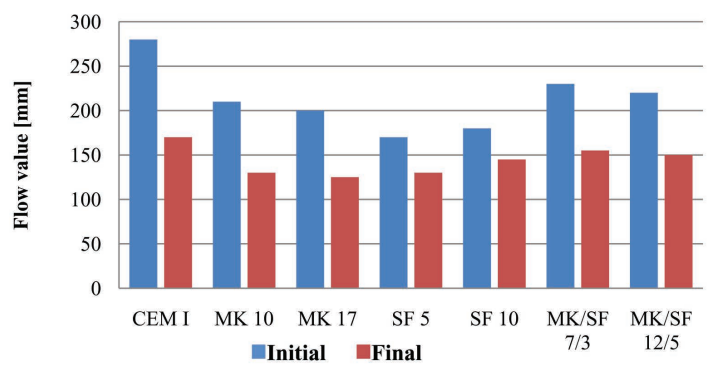

Fig. 4. Initial and final (120 mins) flow values for the mixtures 4. ábra A keverékek terülése kezdetben és 120 perc után

The highest change in the workability was found in the reference mixture and the decrease in flow values were less for the samples made with SCMs. According to the test results, the increasing replacement ratio of each SCM results the decrease of flow values. The same effect was found in case of combined application of MK and SF. The consistence of the reference mixture changed in the largest extent in time (measured up to 120 minutes) compared to the consistencies of the other mixtures. Studying the fresh properties (such as consistence) is, therefore, important in practical applications where SCMs are used in cement mortars.

\subsection{Flexural tensile strength and compressive strength of hardened mortar}

The flexural tensile strength measurements were carried out on hardened prisms by three point bending tests on standard geometry mortar specimens (Haegermann-type prisms with $40 \times 40 \times 160 \mathrm{~mm}$ dimensions) at the age of 28,56 and 90 days. Specimens of mixtures were stored in two different conditions between the age of 28 and 90 days as it was detailed above 
(notations: 'wet' specimens = stored in water; 'conditioned' specimens $=$ stored in climate chamber, $20 \pm 3^{\circ} \mathrm{C}, \mathrm{RH}=65 \%$ ). Figs. 5 and 6 demonstrate the flexural tensile strength values of 'conditioned' and 'wet' specimens as a function of time.

The compressive strength tests were carried out on hardened mortar half-prisms after the bending tests, at the same ages (26, 56, 90 days). Figs. 7 and 8 illustrate the compressive strength values of the 'conditioned' and 'wet' specimens as a function of time. The tests were carried out according to the EN 101511:1999/A1:2006 European Standard [19].

Differences between the flexural tensile strength values of the 'conditioned' and 'wet' samples were recognized. The same tendencies with different extent were found as a function of age of specimens. It can be seen, that the specimens which were saturated with water ('wet'), had higher strength values than that of the samples conditioned in climate chamber. The observation is the opposite in the case of compressive strength values. Compressive strength is smaller for specimens tested in "wet" condition. Similar observations are found in the literature for the influence of water content on flexural tensile strength and compressive strength of concrete [20,21].

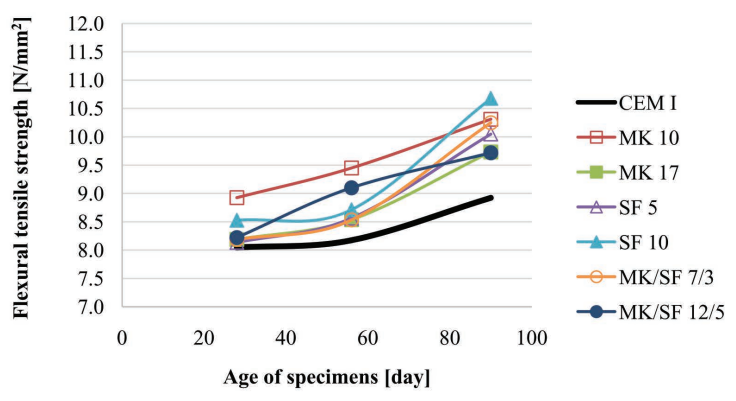

Fig. 5. Flexural tensile strength of 'conditioned' specimens

5. ábra Klímakamrában tárolt próbatestek hajlitó-húzószilárdsága

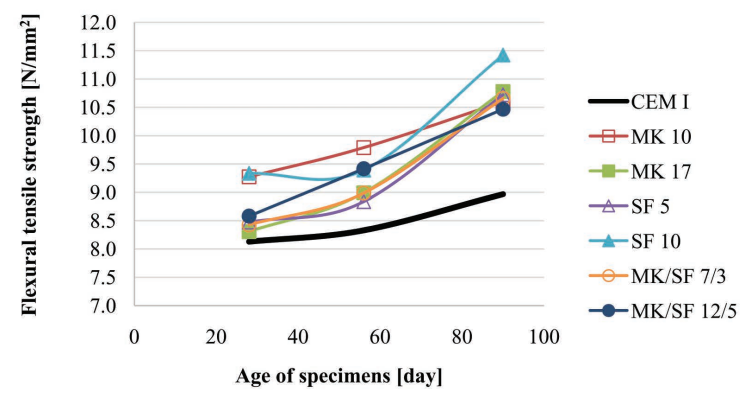

Fig. 6. Flexural tensile strength of 'wet' specimens

6. ábra Víz alatt tárolt próbatestek hajlitó-húzószilárdsága

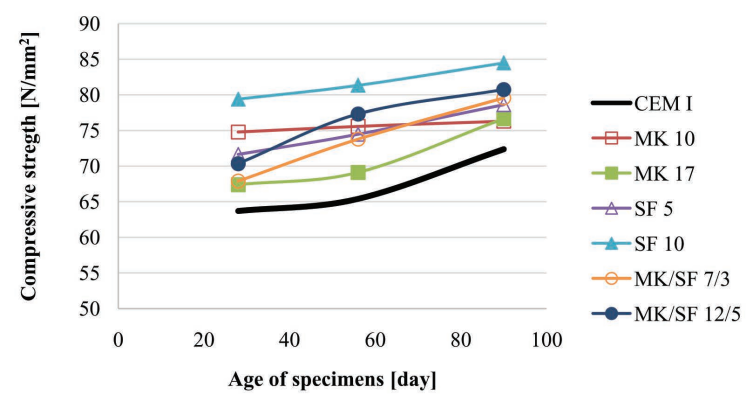

Fig. 7. Compressive strength of 'conditioned' specimens

7. ábra Klímakamrában tárolt próbatestek nyomószilárdsága

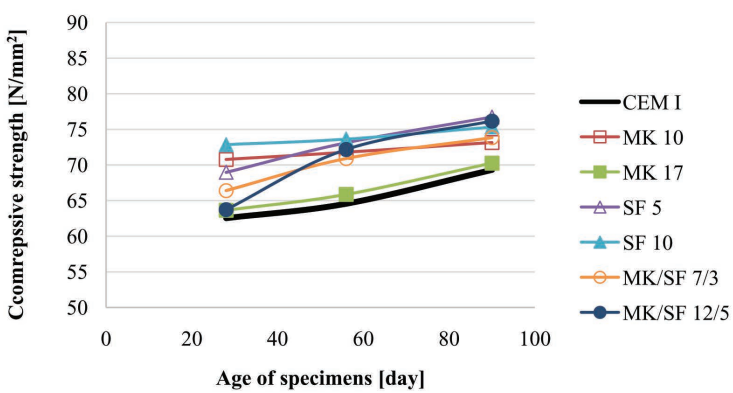

Fig. 8. Compressive strength of 'wet' specimens

8. ábra Víz alatt tárolt próbatestek nyomószilárdsága

According to the measured data, specimens containing SCM had higher flexural tensile strength and compressive strength than that of the reference samples. In the case of the samples with $\mathrm{MK}$, the smaller substitution ratio $(10 \mathrm{~m} \%)$ was more effective, than the higher substitution ratio $(17 \mathrm{~m} \%)$. The compressive strength of the samples with $17 \mathrm{~m} \%$ substitution ratio is very similar to that of the reference samples. The higher dosage of MK is expectedly resulted in the aggregation of the particles, which could not completely disperse during the sample preparation. The results of the samples with SF were the opposite; the higher substitution ratio $(10 \mathrm{~m} \%)$ was found to be more effective than the smaller substitution ratio (5 $\mathrm{m} \%$ ) in both testing conditions ('conditioned' and 'wet'). In the mixtures made with the combination of the two SCMs, also the higher substitution ratio provided the better results. According to the literature [4], higher dosage of the SCM usually increases the strength. In our experiments this statement fit with the results determined on specimens made with SF or with the combination of MK and SF.

\subsection{Water absorption}

The water absorption measurements were carried out at the same ages as the mechanical tests $(28,56,90$ days). The halfprisms (that became available after the bending tests) were immersed into water, and mass measurements were repeated regularly until constant mass of the specimens was reached. Both 'conditioned' and 'wet' specimens were investigated after the same drying process. Water absorption tests were started on oven dry specimens that were dried at $40 \pm 5^{\circ} \mathrm{C}$ until reaching constant mass before the measurements.

Test results are presented in Figs. 9 and 10. The diagrams show the highest water content as a function of time for both 'conditioned' and 'wet' samples.

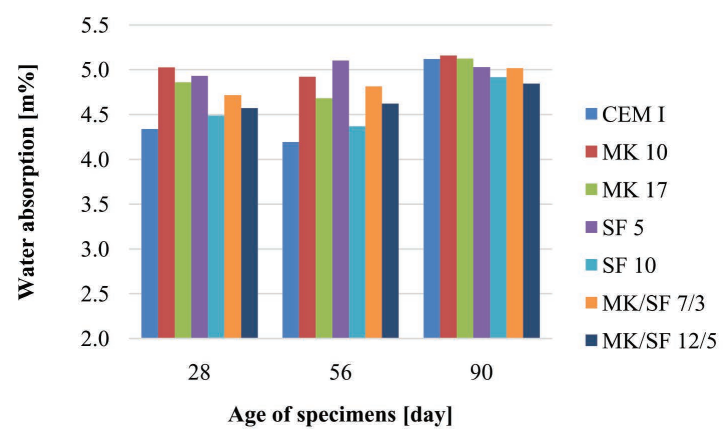

Fig. 9. Water absorption of 'conditioned' specimens 9. ábra Klímakamrában tárolt próbatestek vízfelvétele 


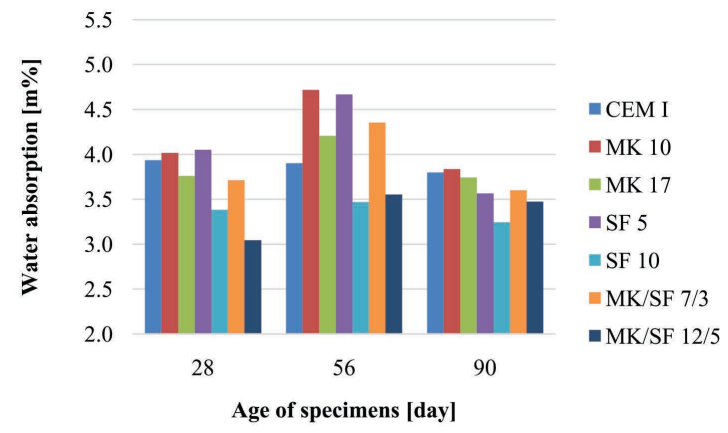

Fig. 10. Water absorption of 'wet' specimens

10. ábra Viz alatt tárolt próbatestek vizfelvétele

After a gentle drying procedure (in $40^{\circ} \mathrm{C}$ in drying cabinet) the water absorption of the 'conditioned' specimens was slightly higher than that of the 'wet' (and dried) samples. A reasonable explanation is that the 'conditioned' samples performed considerable shrinkage, which caused micro-cracks and the porosity of these samples was increased. On the other hand, the hydration of the cement was restricted due to of the lack of external curing water. In the case of 'wet' samples, the hydration was prolonged which resulted lower permeability and lower water absorption.

It can be concluded that the samples (both 'conditioned' and 'wet') showed lower water absorption with higher cement substitution ratio (MK17, SF10 MK/SF 12/5). It can be supposed that the ability of SCMs is better in filling the pores due to their smaller particle size and it can result a more compact structure. On the other hand, higher amount of SCMs can result higher amount of hydrate phases during the pozzolanic reactions.

\subsection{Apparent density}

The apparent density of the hardened mortar depends on the quantity and the density of the components, the air content, the moisture content and the intensity of compaction. Apparent density measurements were carried out according to the EN 1015-10:1999/A1:2006 European Standard [22]. The measured data are represented in Figs. 11 and 12.

The tendencies of the measured data were similar in both cases ('conditioned' and 'wet'); only a slight increase is recognizable in time.

The samples with SCMs had lower apparent density than that of the reference samples. The 'wet' samples had higher apparent density, which can be the result of the formation of the hydrate phases.

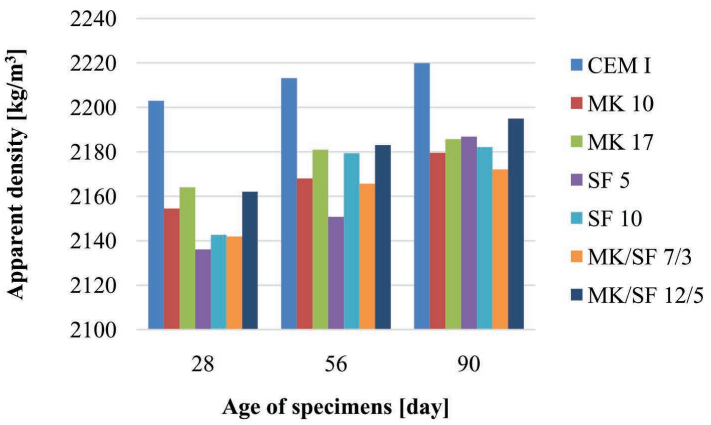

Fig. 11. Apparent density of 'conditioned' samples

Fig. 11. Klímakamrában tárolt próbatestek testsürüsége

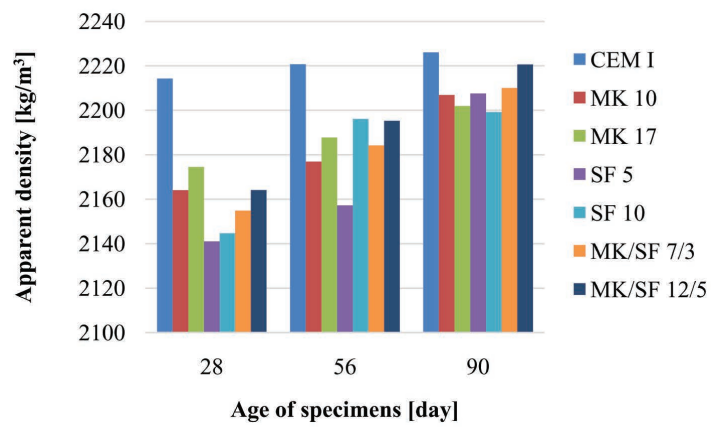

Fig. 12. Apparent density of 'wet' samples

Fig. 12. Viz alatt tárolt próbatestek testsürüsége

\section{5 Apparent porosity}

During drying the samples perform shrinkage and the porosity is increased [23]. The apparent porosity was determined by Eq. (1):

$p_{l}=\frac{w_{f} \cdot \rho_{t}}{\rho_{w} \cdot 100}$

where:

$p_{l} \quad$ - apparent porosity [V\%],

$w_{f} \quad$ - water absorption [m\%],

$\rho_{t} \quad-$ oven dry apparent density $\left[\mathrm{kg} / \mathrm{m}^{3}\right]$,

$\rho_{w} \quad-$ density of water $\left[\mathrm{kg} / \mathrm{m}^{3}\right]$.

Figs. 13 and 14 represent the calculated data from the measurements.

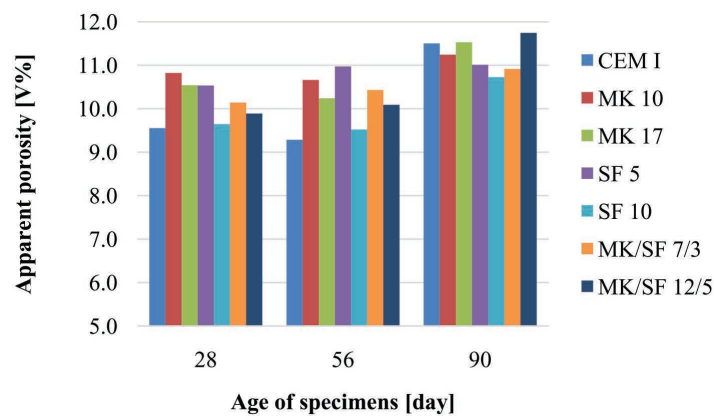

Fig. 13. Apparent porosity of 'conditioned' samples

Fig. 13. Klímakamrában tárolt próbatestek látszólagos porozitása

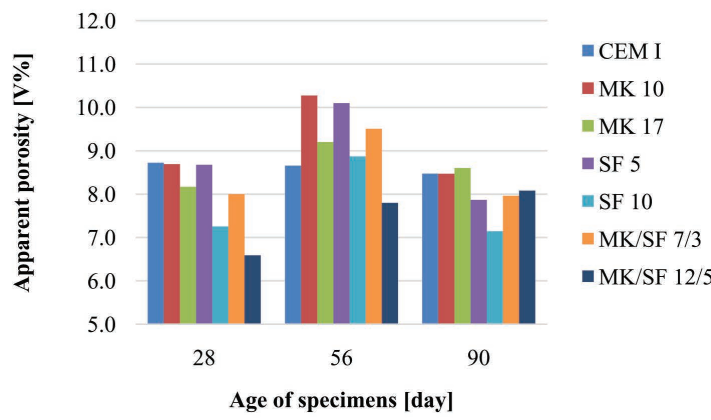

Fig. 14. Apparent porosity of 'wet' samples

Fig. 14. Viz alatt tárolt próbatestek látszólagos porozitása

The 'conditioned' samples had higher apparent porosity due to the presence of more open pores. In the case of 'wet' samples the hydration mechanism continued and more pores could be closed. 
The apparent porosity was higher for the samples with smaller cement substitution ratios. In the case of higher cement substitution ratios, there are more small particles available in the system and it can cause a more compact structure, which decreases the amount of the open pores and decreases the apparent porosity as well.

\section{Conclusions}

Based on the test results it can be concluded that the application of SCMs does not have disadvantageous influence on the properties of cement mortars in fresh and hardened condition.

Differences were observed between the properties of the mixtures in the fresh condition. Addition of SCMs is resulted in decrease of consistence, however, the change of workability in time is less pronounced than that of the reference cement mortar.

Different curing conditions resulted differences in the properties of hardened samples. Flexural tensile strength was higher and compressive strength was lower for the specimens stored under water and tested in wet condition when compared to the results obtained for specimens tested in air dry condition. Water absorption and apparent porosity were lower and apparent density was higher for the specimens stored under water than those of the specimens stored in climatic chamber. The differences are attributed on one hand to the presence of the water and on the other hand to the different rates of hydration due to different curing methods.

The composition and the cement substitution ratios induced further differences. The specimens with smaller substitution ratio showed more effective utilization of SCMs in the view of strength. The water absorption and apparent porosity were higher, but the apparent density was smaller than those of the mixtures with higher substitution ratios.

It is important to find optimum dosage and substitution ratio, because application of SCMs over the optimum amount may reduce the performance both in strength and durability parameters.

\section{Acknowledgement}

The financial support of the Hungarian Scientific Research Fund (OTKA) is highly appreciated (Project No. OTKA T 109223).

\section{References}

[1] Gartner, E. (2004): Industrially interesting approaches to 'Low- $\mathrm{CO}_{2}$ ' cement. Cement and Concrete Research, Vol. 34, No. 9, pp. 1489-1498. http://dx.doi.org/10.1016/j.cemconres.2004.01.021

[2] Owaid, H. M. - Hamid, R. - Taha, M. R. (2012): A review of sustainable supplementary cementitious materials as an alternative to all-Portland cement mortar and concrete. Australian Journal of Basic and Applied Sciences, Vol. 6, No. 9, pp. 287-303. http://ajbasweb.com/old/ajbas/2012/Sep\%202012/287-303.pdf

[3] Chandra, S. (1997): Waste Materials Used in Concrete Manufacturing. Noyes Publication, Göteborg

[4] Siddique, R. - Khan, M. I. (2011): Supplemetary Cementing Materials. Springer - Verlag, Berlin

[5] Yang, K. H. - Jung, Y. B. - Cho, M. S. - Tae, S. H. (2015): Effect of supplementary cementitious materials on reduction of $\mathrm{CO}_{2}$ emissions from concrete. Journal of Cleaner Production, Vol. 103, pp.774-783. http://dx.doi.org/10.1016/j.jclepro.2014.03.018

[6] Ilić, B R. - Mitrović, A. A. - Miličić, L R. (2010): Thermal treatment of kaolin clay to obtain metakaolin, Hemijska Industrija, Vol. 64, pp. 351-356. http://www.doiserbia.nb.rs/Article.aspx?id=0367-598X1000014I
[7] Khan, M. I. - Siddique, R. (2011): Utilization of silica fume in concrete: Review of durability properties, Resources, Conservation and Recycling, Vol. 57, pp. 30-35 http://dx.doi.org/10.1016/j.resconrec.2011.09.016

[8] Siddique, R. (2011): Utilization of silica fume in concrete: Review of hardened properties, Resources, Conservation and Recycling, Vol. 55, pp.923-932. http://dx.doi.org/10.1016/j.resconrec.2011.06.012

[9] Hillemeier. B. - Hüttl, R. (2000): Säureresistenter Beton mit einstellbarer Festigkeit für den höchsten Kühlturm der Welt, Proceedings of Ulmer Beton- und Fertigteil-Tage (Ulm), pp. 142-157.

[10] Siddique, R. (2008) Waste Materials and By-Products in Concrete Springer - Verlag, Berlin.

[11] Nehme, S. G. (2015): Influence of supplementary cementing materials on conventional and self compacting concretes - Part. 1. Literature review. Építöanyag - Journal of Silicate Based and Composite Materials, Vol. 67, No. 1, pp. 28-33. (in Hungarian)

http://dx.doi.org/10.14382/epitoanyag-jsbcm.2015.6

[12] Nehme, S. G. (2015): Influence of supplementary cementing materials on conventional and self compacting concretes - Part. 2. Laboratory tests. Építőanyag - Journal of Silicate Based and Composite Materials, Vol. 67, No. 2, pp. 71-78. (in Hungarian)

http://dx.doi.org/10.14382/epitoanyag-jsbcm.2015.12

[13] Borosnyói, A. (2015): Development of compressive strength of HPC with the use of supplementary cementing material (SCM) combination. Építöanyag - Journal of Silicate Based and Composite Materials, Vol. 67, No. 3, pp. 110-115. http://dx.doi.org/10.14382/epitoanyag-jsbcm.2015.18

[14] El Mir, A. - Nehme, S. G. - Nehme, K. (2016): In situ application of high and ultra high strength concrete. Építőanyag - Journal of Silicate Based and Composite Materials, Vol. 68, No. 1, pp. 20-23. http://dx.doi.org/10.14382/epitoanyag-jsbcm.2016.4

[15] EN 1015-3:1999/A2:2006: Methods of test for mortar for masonry - Part 3: Determination of consistence of fresh mortar (by flow table)

[16] Zhang, M. H. - Malhotra, V. M. (1995): Characteristics of a thermally activated alumino-silicate pozzolanic material and its use in concrete. Cement and Concrete Research, Vol. 25, No. 8, pp. 1713-1725. http://dx.doi.org/10.1016/0008-8846(95)00167-0

[17] Courard, L. - Darimont, A. - Schouterden, M. - Ferauche, F. - Willem, X. - Degeimbre, R. (2003): Durability of mortars modified with metakaolin. Cement and Concrete Research, Vol. 33, No. 9, pp. 1473-1479. http://dx.doi.org/10.1016/S0008-8846(03)00090-5

[18] Bhagavatheswaran, E. S. - Parsekar, M. - Das, A. - Le, H. H. - Wiessner, S. - Stöckelhuber, K. W. - Heinrich, G. (2015): Construction of an Interconnected Nanostructured Carbon Black Network: Development of Highly Stretchable and Robust Elastomeric Conductors. The Journal of Physical Chemistry C, Vol. 119, No 37, pp. 21723-21731. http://dx.doi.org/10.1021/acs.jpcc.5b06629

[19] EN 1015-11:1999/A1:2006: Methods of test for mortar for masonry Part 11: Determination of flexural and compressive strength of hardened mortar

[20] Neville. A. M. (1995): Properties of Concrete, Prentice Hall, Essex, p. 844.

[21] Mindess, S. - Young, J. F. (1981): Concrete, Prentice Hall, Englewood Cliffs, p. 671

[22] EN 1015-10:1999/A1:2006: Methods of test for mortar for masonry - Part 10: Determination of dry bulk density of hardened mortar

[23] Güneyisi, E. - Gesoğlu, M. - Mermerdaş, K. (2008): Improving strength, drying shrinkage, and pore structure of concrete using metakaolin. Materials and Structures, Vol. 41, No. 5, pp. 937-949. http://dx.doi.org/10.1617/s11527-007-9296-Z

Ref.:

Mlinárik, Lilla- Kopecskó, Katalin- Borosnyói, Adorján: Properties of cement mortars in fresh and hardened condition influenced by combined application of SCMs

Építőanyag - Journal of Silicate Based and Composite Materials, Vol. 68, No. 2 (2016), 62-66. p.

http://dx.doi.org/10.14382/epitoanyag-jsbcm.2016.11 